\title{
三陸海岸地域およびヒ口におけ COMPARATIVE STUDY OF URBAN る津波復興・防災計画の比較 \\ RECOVERY PLANNING AND \\ DESIGNING FOR TSUNAMI HAZARD BETWEEN SANRIKU COASTAL AREA AND HILO
}

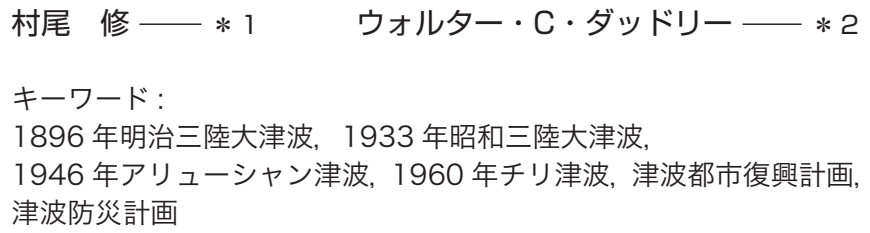

The 1896 Sanriku Tsunami, The 1933 Sanriku Tsunami, The 1946 Aleutian Tsunami, The 1960 Chilean Tsunami, Post-tsunami urban recovery planning, Urban safety planning for tsunami
Osamu MURAO — $* 1 \quad$ Walter C. DUDLEY — $* 2$

Having some similarities as tsunami-prone areas, Sanriku Coastal Area, Japan, and Hilo, Hawaii, experienced several devastating tsunamis and recovered in their history. However, the post-tsunami urban recovery planning and the future strategy for tsunami management present differences in both areas. Demonstrating timeline of the affected tsunamis and the published planning and policies for tsunami disaster management, this paper compares the history of urban recovery planning and designing for tsunami hazard in the United States and Japan. It also examines the contents for urban safety management in recent governments' guidelines to share useful information for the future planning strategy.
1.はじめに

\section{1 研究の背景と目的}

ハワイ島に位置するヒロと三陸沿岸地域は，これまでに幾度もの 津波災害を経験している津波常襲地域である。1960 年の 5 月にはチ リ地震により発生した津波により，両地域とも被災するなど立地的 な共通点も多いが，その一方で復興のなされ方にはいくつかの相違 もみられる。一般的に, ある地域が自然災害により被災した後には, その経験を教訓として, 将来の災害が軽減されるよう復興計画が策 定されるが，それは一様ではなく，時代や地域ごとの様々な背景に より異なっている。本稿を執筆している 2010 年は前述したチリ津波 から 50 周年にあたる。この 50 年間に，三陸の各地区とヒロはそれ ぞれの事情の中で復興を成し遂げ，また日米の津波研究も進展し， それぞれ都市の体系的な津波防災の考え方も確立されてきた。

本稿では，ヒロと三陸沿岸地域（岩手県と宮城県）における 19 世紀末以降の津波災害と復興を含む変遷を振り返り, 近年の日米の 体系的な津波都市防災計画をふまえ，比較する。1960 年チリ津波か ら 50 年が経過した現時点において, あらためて情報を整理し, 時代 や地域による差異や共通点を考察することにより，今後の津波防災 に資する知見を得ることを目的としている。

\section{2 既往研究および研究の方法}

本研究の対象となる三陸海岸地域とヒロにおける津波被害および 復興の文献は多々存在する。まず三陸沿岸地域の被災と復興に関す る情報を得るために，山下 ${ }^{1)-4)}$ ，吉村 ${ }^{5)}$ による各文献と中央防災会 議「災害教訓の継承に関寸る専門調査会」がまとめた「1896 明治三

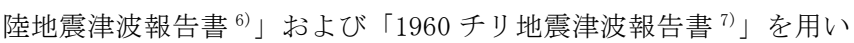
る。ヒロおよび八ワイの被災と復興に関しては, Dudley らおよび USGS による資料 ${ }^{8-10)}$ を用いることにする。日米の津波災害対策や津 波復興の比較に焦点をあてた研究は, 筆者の調べた範囲では見あた
らないが，首藤が既往文献の中で日本での防災対策を述べる際にア

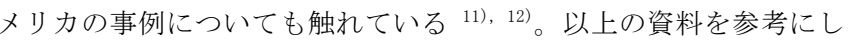

て, 三陸海岸およびヒロの被災と復興の経緯について整理し, 発生 した津波災害とその後の復興および津波防災上の重要な出来事を時 系列で整理し(年表の作成), 考察する。

次に, 現代における日米の最新の津波復興施策について整理し, 得られた年表に基づき, 両地区で各時代に施された都市復興と津波 防災施策の変遷を考慮しながら, 両地区の比較を行う。なお, 筆者 はヒロにおける津波後の津波復興について既に報告している ${ }^{13)}$ が, ここではそれらの情報も取り入れながら，考察する。

\section{2. 津波常襲地域としてのヒロと三陸海岸の概要}

表 1 に 19 世紀以降に両地域で発生した主な津波（最大波高）と死 者・行方不明者を示す。またヒロおよび三陸海岸の各地の配置を同 縮尺で表したものを図 1 に示す。それぞれハワイ島および本州の東 側に位置しており, 太平洋に面している。ともに地震, 津波, 火山 活動による災害の多い地域であり, 過去に近海, 太平洋, および南 北アメリカ大陸で発生した地震による津波の影響を多く受けてきた。

表 1 三陸海岸およびヒロにおける主な津波と死者・行方不明者

\begin{tabular}{|c|c|c|c|}
\hline 発生日 & 震源／津波名 & 三陸海岸地域 1), 15) & ヒロ 14) \\
\hline 1837.11.7 & チリ & & 14 人 $(6.0 \mathrm{~m})$ \\
\hline 1877.5 .10 & チリ & & 5 人 $(4.8 \mathrm{~m})$ \\
\hline 1896.6.15 & 明治三陸 & 約 2.2 万人 $(38.2 \mathrm{~m})$ & \\
\hline 1923.2.3 & カムチャッカ & & 1 人 $(6.1 \mathrm{~m})$ \\
\hline 1933.3 .3 & 昭和三陸 & 3,064 人 $(28.7 \mathrm{~m})$ & \\
\hline 1946.4.1 & アリューシャン & & 96 人 $(16.4 \mathrm{~m})$ \\
\hline 1960.5 .23 & チリ & 182 人 $(6 \mathrm{~m})$ & 61 人 $(10.5 \mathrm{~m})$ \\
\hline
\end{tabular}

1筑波大学大学院システム情報工学研究科 准教授・博士 (工学) （テ 305-8573 つくば市天王台 1-1-1）

Assoc. Prof., The Graduate School of Systems and Information Engineering, The Univ. of Tsukuba, Dr. Eng.

Prof., The Univ. of Hawaii at Hilo, Ph. D. 
ヒロはハワイ郡の郡庁所在地であり，ホノルルに次ぐハワイ州第 二の都市 (人口 40,759 人注 1 ) である。その立地から津波を受けや すく, 19 世紀以降にハワイで発生した津波による死者合計 291 人の うち, 60.8\%の 177 人がヒロで亡くなっている。ヒロの地勢は弓状の 湾に沿って広がる緩やかに傾斜している平地であり, 19 世紀末以降, 湾岸地域を中心に発展してきたが, 幾度かの津波被害を体験し, そ の復興の際にそれまで街として栄えていた沿岸住宅地に建築規制を しき，現在では津波被害抑止のための緑地帯が広がっている ${ }^{13)}$ 。

一方, 三陸地域も津波常襲地として知られており, 越村 ${ }^{16)}$ にる と「現存している資料から判断すると, 平均で 46 年に一度津波が発 生していた」地域である。宮城県の女川から岩手県北端の種市まで $300 \mathrm{~km}$ ほどの海岸線に沿って立地していた集落が過去の津波により 甚大な被害を受けてきた。1896 年明治三陸津波時の被災町村数 ${ }^{1}{ }^{1}$ は 岩手県と宮城県で 54 , 集落 (字) 数はおよそ 250 であり, 町村あた りの被災前人口は少ないところで 111 人 (岩手県高田町), 最も多い ところで 6,986 人（岩手県釜石町）であった。集落（字）の人口は ほとんどが数百名というオーダーである。その後, 町村同士の合併 等が進み, 現在では種市町から女川町までの範囲で 17 の市町村に統 合されている。同じ津波常襲地であってもその地勢はヒロとは異な り，三陸地域はリアス式海岸であるため，三方を険しい山に囲われ た地区も少なくない。社会背景と時代背景とともに, このような地 形の違いも津波後の復興施策に影響を与えてきた。

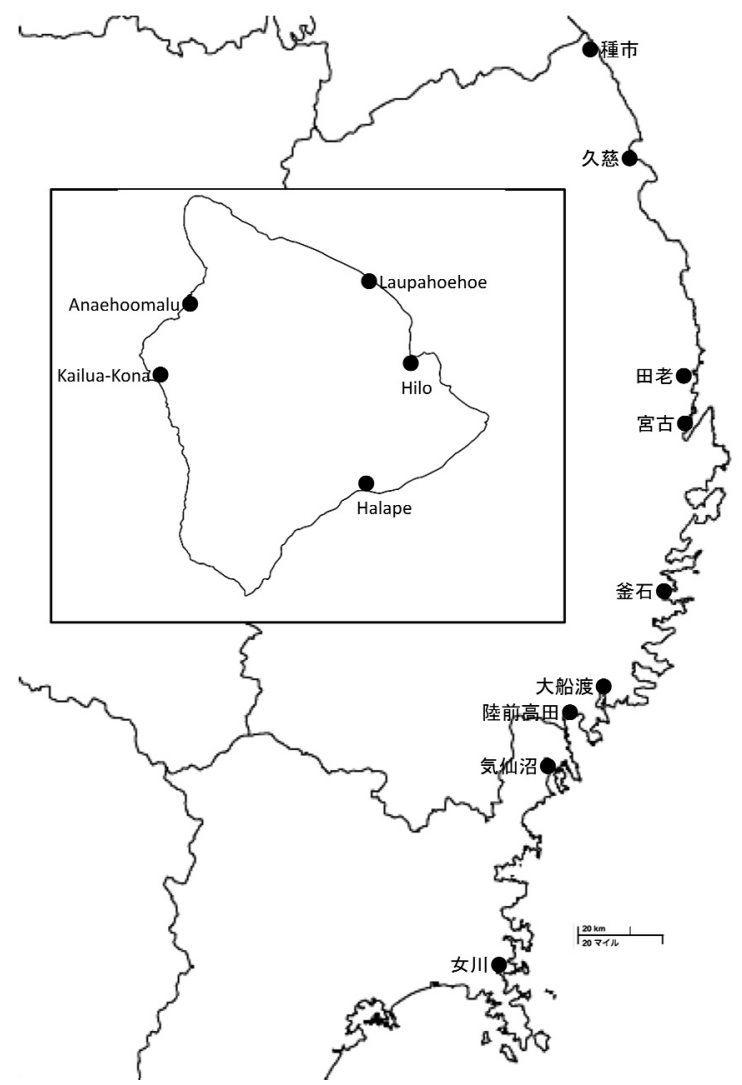

図 1 ヒロおよび三陸沿岸地域の位置図（同縮尺で比較）

\section{3．津波による被災と復興の経緯}

ここでは，我が国および八ワイ（あるいは米国）の津波防災に大 きな影響を与えてきた三陸海岸地域およびヒロにおける津波災害と
その復興を軸に据えつつ, 両国における 19 世紀後半以降の都市の津 波防災に関する歴史的事項を併記してその経緯を把握することにす る。表 2 は, 1.2 で挙げた参考文献に基づき作成した三陸海岸地域 (日本) およびヒロ (ハワイ) における津波と都市復興関連年表で ある。一般的に, 壊滅的な都市災害がその後の都市防災に大きな影 響を与えるという事実は，歴史が示してきたとおりであるが，津波 災害も例外ではない。ここでは三陸海岸地域（日本）における津波 防災の経緯を, 藤間 ${ }^{18)}$ による分類を参考にし, 明治三陸津波 (1896 年), 昭和三陸津波 (1933 年), チリ津波 (1960 年), そして「地域 防災計画における津波対策強化の手引き $\left.{ }^{19}\right\rfloor$ の策定時（1997 年）の 前後で $5 つ （[J 1]$ か $[\mathrm{J} 5] ）$ に区切った。またヒロ（ハワイ）にお ける経緯を, マスタープラン作成時（1940 年), アリューシャン津 波（1946 年), チリ津波（1960 年), そして Designing for Tsunami ${ }^{22)}$ の策定時（2001 年）の前後で $5 つ （[H 1]$ から [H5]）に分類した。以 下に両地域における各時代の大筋を述べる。

\section{1 三陸海岸地域（日本）における津波都市防災の系譜}

1896 年明治三陸津波以前（J1）はまだ津波現象が科学的に解明さ れていない時代であった。しかし 1854 年安政地震津波の後に, 現代 の津波防災にも繫がる対策が施される。和歌山の広町で堤防と松並 木が整備され始めたのである。その都市防災上の効果の判定は, お よそ 90 年後の 1946 年南海地震まで待たねばならなかった。

明治三陸津波の後（J2）も因襲的な考え方は続いていた。多くの 被災集落では高所移転の必要性が議論されるが，まだ国や県をあげ ての復興事業は実施されず, 地元の有力者の先導や個人的な事情に より移転は進められた。結局 43 箇所（内集団移転 7 箇所）で高所移 転がなされたが，多くが元の場所に戻ってきてしまった。高所移転 の他にも, 避難路整備, 防潮林の育成などが提案されたが, 実現に は至らなかった。この時代にラジオ放送が開始され, 後の時代に重 要な津波警報の媒体となっていく。

1933 年昭和三陸津波の後（J3）には科学的根拠に基づく復興の考 え方も反映されるようになり, 不十分ながら国や県による支援体制 も築かれていく。復興の基本的な考え方（高地移転，防浪堤，防潮 林, 護岸, 防浪地区, 緩衝地区, 避難道路, 津浪警戒, 津波避難, 記念事業）は「津浪災害予防に関する注意書 ${ }^{23)} 」 に$ 示され，その後， 各地に防潮林が造成され, 護岸整備も始まった。戦後は防潮堤等の 建設も本格的になり，1950 年代には津波予報が開始される。

1960 年チリ津波後には防潮堤や防波堤が建設・強化されるなど, 高度経済成長とともに都市津波防災の物的環境が各地で整備されて いく。そして土地利用規制も布かれ, 災害を通じて津波防災上の規 制の効果が見られるようになってきた。1970 年代になると, ハード 面のみならずソフト面の防災も始まり, 津波浸水予想図, 津波情報 システム, 津波教育など活動も実施されるようになる。

1960 年チリ津波後の 30 年間の津波防災対策と津波災害を通じて, 総合的な防災対策の必要性が高まり, その結果生まれたのが「地域 防災計画における津波対策強化の手引き」および「津波災害予測マ ニュアル」の策定であった。それ以降（J5）は，各地で八ザードマ ップや津波避難ビルなどの整備が進められて, 今日に至っている。

\section{2 ヒロ (ハワイ) における津波都市防災の系譜}

ハワイ王国は 19 世紀末にアメリカに併合され, ヒロでは 20 世紀 前半 (H1) に現在のダウンタウンを中心とした街が形成されていく。 
表 219 世紀後半以降の三陸海岸地域（日本）およびヒロ（ハワイ）における津波と都市復興関連年表

\begin{tabular}{|c|c|c|}
\hline 西暦 & 三陸海岸地域（日本）における主なできごと & ヒロ（ハワイ）における主なできごと \\
\hline 1854 & 安政東海・南海地震津波（320人＋713人） & [H1] \\
\hline 1858 & 和歌山広町で浜口悟陵が土堤の築造と植樹 & \\
\hline 1868 & & ハワイ地震津波 (47人) \\
\hline 1877 & & チリ津波 (5人) \\
\hline 1888 & 東京市区改正条例交付 & \\
\hline 1896 & $\begin{array}{l}\text { 明治三陸津波（約 } 2.2 \text { 万人) } \\
\text { 三陸沿岸縦貫鉄道敷設計画（実現せず） } \\
\text { 高所移転 } 43 \text { 箇所（うち集団移転7箇所），しかし多くが元の場所に戻る }\end{array}$ & \\
\hline 1899 & & The Hilo Railway (The Hawaii Consolidated Railway) 開通 \\
\hline 1908 & & 防波堤建設開始 \\
\hline 1919 & 市街地建築物法・都市計画法 (旧法) 制定 & \\
\hline 1920 & & 初の公共ラジオ放送開始 \\
\hline 1923 & 関東地震津波（109人） & カムチャッカ津波 (1人) \\
\hline 1925 & 日本初のラジオ放送開始 & \\
\hline 1929 & & 防波堤完成 \\
\hline 1933 & $\begin{array}{ll}\text { 昭和三陸津波 (約 } 3,064 \text { 人含北海道) } & \text { [J3] } \\
\text { 文部省震災予防評議会「津浪災害予防に関する注意書」の提案 } & \\
\text { 関東大震災 } 10 \text { 周年記念碑建立事業 } & \\
\end{array}$ & 三陸の地震による津波警報が発せられるが，まだ不十分 \\
\hline 1934 & $\begin{array}{l}\text { 宮城：県による建築規制, 記念碑募集標語の記事記載 } \\
\text { 内務省復興計画 } \\
\text { 防潮林の建設 }\end{array}$ & \\
\hline 1936 & 津浪予報塔が釜石に建設 & \\
\hline 1941 & 三陸沿岸を対象に津波警報組織発足 & 都市マスタープラン発表 \\
\hline 1944 & 東南海地震津波（1,223人震害含） & \\
\hline 1946 & 南海地震（約 1,400 人震害含）和歌山広町の防潮堤が効果を発揮 & アアリューシャン津波（96人十ハワイ州63人） \\
\hline 1948 & & 沿岸測地局による津波警報システム運用開始 \\
\hline 1949 & $\begin{array}{l}\text { 高知県災害救助隊規則の作成 } \\
\text { 「津波予報伝達総合計画」閣議了承，総合テストの実施 }\end{array}$ & 太平洋津波警報センター設立（NOAAの一部として） \\
\hline 1951 & 国内で最初の津波予報実施 & \\
\hline 1952 & 十勝沖地震津波：前年開始された津波予報システムが効果を発揮 & カムチャッカ津波 (0人) \\
\hline 1957 & & アリューシャン津波 (0人) 沿岸住宅被災, PTWSが機能し人的被害無 \\
\hline 1958 & 「海岸保全施設築造基準」制定 & \\
\hline 1960 & $\begin{array}{l}\text { チリ津波（182人） } \\
\text { 北海道浜中町の災害危険区域と建築制限 }\end{array}$ & $\begin{array}{l}\text { チリ津波 (61人) 津波警報変更により意味が住民に伝わらず } \\
\text { Hawai'i Redevelopment Agency設立 } \\
\text { 沿岸緩衝帯拡幅と埋立による沿岸開発等を検討 }\end{array}$ \\
\hline 1961 & $\begin{array}{l}\text { チリ地震津波災害対策事業計画（策定基淮，事業量，津波防波堤計画） } \\
\text { 大船渡湾口に世界最初の津波防波堤建設 } \\
\text { 名古屋市臨海部防災区域建築条例による区域指定 }\end{array}$ & \\
\hline 1964 & & アラスカ地震津波 一部浸水 (0人) \\
\hline 1965 & & KAIKO'Oプロジェクト発表 \\
\hline 1966 & チリ津波緊急対策終了 & \\
\hline 1967 & & アラスカ津波警報センター設立 \\
\hline 1968 & 十勝沖地震津波（53人） 三陸地方では防波堤等構造物により被害なし & $\begin{array}{l}\text { 太平洋津波警報センター設立 } \\
\text { The National Flood Insurance Program (NFIP) }\end{array}$ \\
\hline 1969 & 都市計画法 (新法) 施行 & \\
\hline 1972 & & The 1972 Coastal Zone Management Act (CZMA) \\
\hline 1974 & & Hilo Downtown Development Plan認可 \\
\hline 1975 & & ハワイ地震津波 (2人) \\
\hline 1977 & 静岡で津波浸水予想図を公表 & \\
\hline 1979 & 海底地震常時監視システム運用開始（気象庁） & \\
\hline 1983 & $\begin{array}{l}\text { 津波常襲地域総合防災対策指針（案）作成（建設省/水産庁） } \\
\text { 日本海中部地震津波（104人） }\end{array}$ & \\
\hline 1984 & 唐桑津波体験館設立 & \\
\hline 1985 & & $\begin{array}{l}\text { Downtown Hilo Redevelopment Plan認可 (Chapter 27:Flood Control } \\
\text { of the Hawaii County Code) }\end{array}$ \\
\hline 1991 & & The 1st Evacuation maps for Hawaii 公開 \\
\hline 1993 & 北海道南西沖地震津波（200人震害含） & \\
\hline 1994 & 津波地震早期検知網の運用開始（気象庁） & The Pacific Tsunami Museum設立 \\
\hline 1997 & $\begin{array}{l}\text { 「地域防災計画における津波対策強化の手引き」および } \\
\text { 「津波災害予測マニュアル」の策定（国土庁ほか) }\end{array}$ & State Emergency Alert System (EAS) 運用開始 \\
\hline 1998 & & The Pacific Tsunami Museum開館 \\
\hline 1999 & 津波予報区域の拡大と予測精度の向上 (気象庁) & \\
\hline 2001 & & Designing for Tsunamis公開 \\
\hline 2003 & 十勝沖地震津波 (2人) & \\
\hline 2004 & $\begin{array}{l}\text { 「津波・高潮ハザードマップマニュアルの概要」発行（国土交通省） } \\
\text { 自治体による津波ハザードマップ公開率 }(9.6 \%)\end{array}$ & EnVision Downtown Hilo 2025活動開始 \\
\hline 2005 & $\begin{array}{l}\text { 「津波避難ビル等に係るガイドライン」発行（内閣府） } \\
\text { 大規模津波防災総合訓練実施（国土交通省） }\end{array}$ & \\
\hline 2006 & $\begin{array}{l}\text { 緊急地震速報を活用した津波警報・注意報の迅速化（気象庁） } \\
\text { 自治体による津波ハザードマッフ公開率 }(34.9 \%) 17)\end{array}$ & \\
\hline 2008 & & Guidelines for Design of Structures for Vertical Evacuation from Tsunamis公開 \\
\hline
\end{tabular}


この時代にサトウキビ産業等を支える鉄道が開通し，安全な海上交 通のために防波堤も建設される。

1940 年前半（H2）には他のアメリカの都市同様, ヒロでもマスタ ープラン ${ }^{20)}$ が作成されるが，ここではまだ津波防災については触れ られていない。しかしながらこの中で, 当時は住宅が密集していた 沿岸部を緑地帯に変える有用性が記されており, それが後の沿岸部 の建築規制への布石となったとみることができる ${ }^{13)}$ 。

1946 年アリューシャン津波では沿岸部にあった多くの住宅が壞 滅した。その後（H3）の復興時には, 沿岸部の建築を禁止し, 都市 規模の緑地帯に変更する動きが始まるが, 原地で復興した住宅もあ り，それらは1960 年の津波により再度被害を受けることになる。日 本と同様，この時代に津波のメカニズムなどが解明されるようにな り，それが津波警報システムの運用開始へと繋がっていく。

1960 年チリ津波では, 1946 年の津波とほぼ同じ地区が被害を受け, 街は壞滅状態になった。その後 (H4), 沿岸部を都市緑地として開発

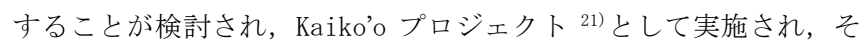
の結果現在見られる沿岸緑地帯が実現された。またこの津波により 日本を含む太平洋地域の各地が被害を受けたことにより, 太平洋津 波警報センターが設立された。1990 年代には EAS が運用され，また 津波教育の拠点として Tsunami Museum が開館する。

近年（H5）では, Designing for Tsunami ${ }^{22)}$ に例示されるように, 都市津波防災の体系的な考え方も提案され, アメリカの諸都市でも これらを参考にする動きが見られる。

\section{4. 津波に関する都市復興・防災計画の比較}

\section{1 日米の津波防災の考え方とスキームの作成}

ここでは, 日米両国政府機関が公表している最近の津波防災計画 に関する文献に基づき, 津波防災の考え方の体系を作成する。日本 の計画としては「津波防災計画における津波対策強化の手引き ${ }^{19)} 」$

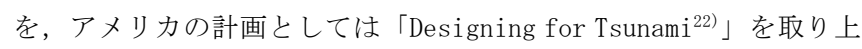
げる。そして「災害対応の循環体系 ${ }^{24)} 」$ の考え方により, 両者を統 合し，比較のためのスキームを作成する。

（1）「津波防災計画における津波対策強化の手引き ${ }^{19)} 」 の$ 概要

この手引きは, 藤間 ${ }^{18)}$ によると, 防潮堤など構造物だけでは抑止 できない津波に対する策として 1997 年にまとめられたものであり, 「防災構造物, 津波に強いまちづくり, 防災体制の三つから成り立 って」いる。ここで描かれた「総合的な対策事業」により，現在各 地で進められているハザードマップの作成や津波避難ビル建設など の防災事業が進められていると言えよう。

(2)「Designing for Tsunami ${ }^{22} 」 の$ 概要

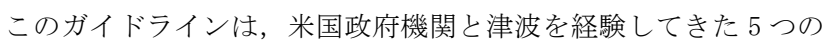
州により, 2001 年に発表された。サブタイトルにあるように, (1)津 波に対する知識, (2)沿岸部の土地利用規制, (3)沿岸部の利用方法, (4)被害を軽減する建築デザイン, (5)沿岸部の再開発, (6)重要施設の 配置，(7)避難，の 7 つ Principles から構成されている。

（3）都市津波防災のスキーム

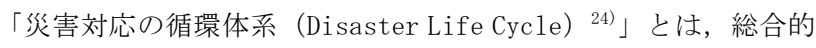
な防災活動を災害発生からの時系列に沿った「災害対応 (Response)」, 「復旧・復興(Recovery/Reconstruction)」, 「被害抑止 (Mitigation)」, 「被害軽減のための事前準備 (Preparedness)」の4つのフェイズに
分類する考え方である。この 4 項目に加え,「災害発生」の前後には 「災害予知と早期警報 (Prediction \& Early Warning)」などのフェ イズを副次的に位置づけている。津波防災の計画も様々な対策があ るため, それらを整理するためにこの考え方を用いた。上に挙げた 2 つの資料に基づき，津波防災の各種対策をこの考え方に則り表 3 のように整理した。縦軸には「災害対応の循環体系」の各フェイズ とその対策項目, 横軸には前章で述べた両地域の時代区分と各時代 で重要な役割を果たした津波後の都市復興計画, 津波防災計画, あ るいは関連する事例が示されている。縦軸の項目は「津波防災計画 における津波対策強化の手引き」と「Designing for Tsunami」に基 づき抽出されているため, 表中にゴシック体文字で示している。

\section{2 日米の津波に関する都市復興・防災計画と変遷の比較}

まず，参考にした日米ふたつの文献の内容を比較する。「津波防災 計画における津波対策強化の手引き」は各自治体が津波災害用の地 域防災計画を作成するためのマニュアルとして発行された一方で,

「Designing for Tsunami」は都市計画と建築設計に資するよう都市 の物的環境に焦点をしぼり作成されている。両者の主旨は異なるが, ここでは都市防災計画と都市復興計画という視点に軸を置き, 整理 している。両者ともハード面, ソフト面から総合的に津波災害を考 えているという点では共通しているが, 構造物に対する記述の仕方 には違いが見られる。「Designing for Tsunami」では, 津波のエネ ルギーに対処するために, 回避 (avoiding), 減速化 (slowing), 制 御 (steering), 遮断 (blocking) に分け, それぞれの効果に対して 構造物の取扱を説明している。このような考え方は, 表 3 にあげた 日本の資料等には見られなかった。また避難については, どちらも 取り上げているが, 「Designing for Tsunami」では水平避難と垂直 避難というょうに分類している。三陸地域では「津波は横に見て逃 げろ」と伝承されてきたようだが，これは「水平方向の避難ではな く, 横方向の高所に上れ」ということである。急傾斜地の多い三陸 では垂直方向の避難は自明のものとしてとらえられており, 平地の 広がるヒロなどでは避難といえば水平方向であったことから，この ように水平避難と垂直避難が認識されているのではないだろうか。 津波記念碑整備や復興時の記念事業などは, アメリカの資料には出 てこない。アメリカでは戦没者の碑に氏名を刻むということが行わ れる。災害時にも同様のことが行われる (ハワイ島の Laupahoehoe の碑など）が，その後の啓発につながる教訓などは刻まれない。一 方で日本では, 昭和三陸津波後に建立された碑に「地震があったら 津波の用心. 津波が来たら高い所へ」と刻まれているように, 災害 の教訓を将来に残寸役割もあった。そのような地域社会の違いが， 津波対策の項目の違いに表れていると見ることができる。

次に各項目が津波復興・防災上の計画あるいは事例として表れて きた経緯について, 考察したい。防潮林と防潮堤（土堤）が造成さ れたのは, 1858 年の安政地震の後の和歌山県においてである。その 後, 明治三陸津波後に分散的ではあったが高地移転がなされ, 昭和 津波の後に国をあげての復興事業が初めて実施される。チリ地震の 後には構造物主体の防災対策が行われるが，一方で三陸地方を対象 とした「津波常襲地域総合防災対策指針（案） ${ }^{25}$ 」でソフト面も議 論されるようになる。そして 1997 年の「津波防災計画における津波

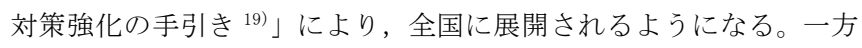
ヒロでは, 湾における安全な海上交通のための防波堤が 1929 年に完 
表 3 三陸海岸地域（日本）およびヒロ（アメリカ）における都市の津波防災対策項目と変遷の比較

\begin{tabular}{|c|c|c|c|c|c|c|c|c|c|c|c|c|c|c|c|c|c|c|c|c|c|}
\hline \multirow{3}{*}{ フェイズ } & \multirow{3}{*}{ 大項目 } & \multirow{3}{*}{ 中項目 } & \multirow{3}{*}{ 小項目 } & \multicolumn{3}{|c|}{\begin{tabular}{l|l}
$\mathrm{J} 1$ & $\mathrm{~J} 2$ \\
\end{tabular}} & \multicolumn{3}{|l|}{$\mathrm{J} 3$} & \multicolumn{3}{|c|}{$\mathrm{J} 4$} & \multicolumn{3}{|c|}{$\mathrm{J} 5$} & H1 & \multicolumn{3}{|c|}{$\begin{array}{ll}\mathrm{H} 2 & \mathrm{H} 3 \\
\end{array}$} & \multirow{2}{*}{\multicolumn{2}{|c|}{ 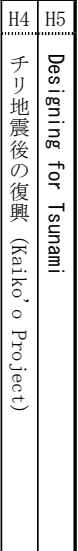 }} \\
\hline & & & & 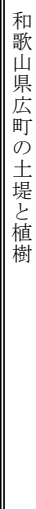 & 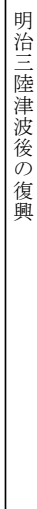 & 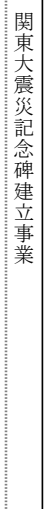 & 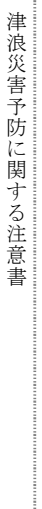 & 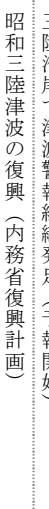 & 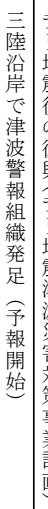 & 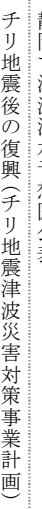 & 清波 & 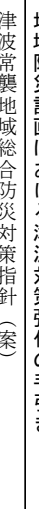 & 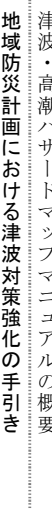 & 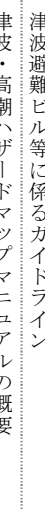 & & 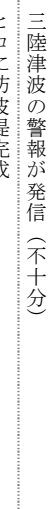 & 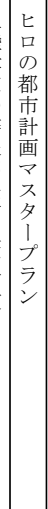 & 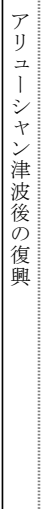 & 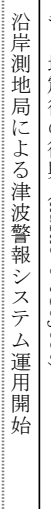 & & \\
\hline & & & & $\mid$\begin{tabular}{|l}
1 \\
8 \\
5 \\
8
\end{tabular} & \begin{tabular}{|l}
1 \\
8 \\
9 \\
6 \\
1
\end{tabular} & $\begin{array}{l}1 \\
9 \\
3 \\
3\end{array}$ & $\begin{array}{l}1 \\
9 \\
3 \\
3\end{array} \mid$ & $\left.\begin{array}{l}1 \\
9 \\
3 \\
4 \\
1\end{array}\right]$ & $\begin{array}{l}1 \\
9 \\
4 \\
1\end{array}$ & $\begin{array}{l}1 \\
9 \\
6 \\
1 \\
1\end{array}$ & $\begin{array}{l}1 \\
9 \\
7 \\
7\end{array}$ & $\begin{array}{l}1 \\
9 \\
8 \\
3\end{array}$ & \begin{tabular}{l|l}
1 & 2 \\
9 & 0 \\
9 & 0 \\
7 & 4
\end{tabular} & & 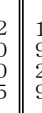 & $\begin{array}{l}1 \\
9 \\
3 \\
3\end{array}$ & $\begin{array}{l}1 \\
9 \\
4 \\
0\end{array}$ & $\left|\begin{array}{l}1 \\
9 \\
4 \\
6 \\
1\end{array}\right|$ & $\begin{array}{l}1 \\
9 \\
4 \\
8\end{array}$ & $\begin{array}{l}1 \\
9 \\
6 \\
5\end{array}$ & $\begin{array}{l}2 \\
0 \\
0 \\
1\end{array}$ \\
\hline \multirow[t]{29}{*}{ 被害抑止 } & 土地利用 & 土地利用規制 & 緩衝带の配置 & & ........ & ........ & 0 & (ㅇ) & $\rightarrow-$ & $\rightarrow$ & $\rightarrow$ & of & $0=$ & $\rightarrow$ & $\rightarrow$ & .......... & o & (0) & $\rightarrow$ & (2) & D \\
\hline & & & 浸水地域の建築制限（防浪地区） & & (3) & 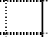 & $0:$ & (2) & $\rightarrow \mathbb{C}$ & (0) & $\rightarrow$ & oli & O= & $\rightarrow$ & $\rightarrow$ & "3' & 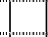 & (Q) & $\rightarrow$ & (Q) & b] \\
\hline & & & 高地移転 & & (2) & $\rightarrow$ & 0. & (0) - & $\rightarrow$ & 0, & $\rightarrow$ & ol & $0=$ & $\rightarrow$ & $\rightarrow$ & "in. & (3) & (2) & $\rightarrow$ & (2) & ] \\
\hline & & & 浸水地域内の計画 (ゾーニング, 配置, インフラ, 重要施設) & & & & & 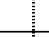 & & (a) & $\rightarrow$ & ol & 0 & $\rightarrow$ & $\rightarrow$ & 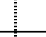 & 0 & $\rightarrow$ & $\rightarrow$ & (0) & ㅁ] \\
\hline & 構造物（植林） & 回避 & ピロティ形式の建築物 & & ....... & ........ & ...... & 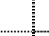 & 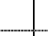 & 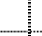 &..- & $\ldots$ & 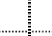 & 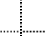 & & 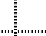 & & (0) & $\rightarrow$ & (ㅇ) & 임 \\
\hline & & & ピロティ形式の土木構造物 & & & 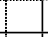 & 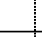 & - & 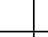 & E- & 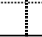 & 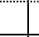 & I & I & 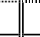 & 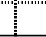 & 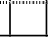 & 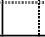 & + & + & ja \\
\hline & & 津波の減衰化 & 防潮林 & (2) & (0) & $\rightarrow$ & O) & (2) & $\rightarrow$ & 0 & $\rightarrow$ & o. & 이 $=$ & $\rightarrow-$ & $\rightarrow$ & ( & 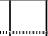 & ...... & ...... & (2) & ] \\
\hline & & & 溝状の空間（水路等） & & & & & & & & & & & & & & & & & & ] \\
\hline & & & 偡斜面 & & & 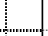 & & 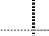 & & & . & & I & - & & & & & & & 밈 \\
\hline & & & 段丘状地形・構造物 & & & & & 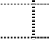 & 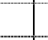 & 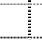 & 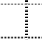 & & 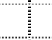 & 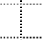 & & & & & & & 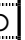 \\
\hline & & & 防壁 & & & & & - & 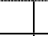 & 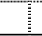 & 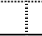 & & 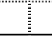 & I & 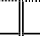 & 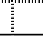 & 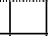 & 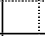 & 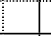 & 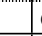 & 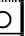 \\
\hline & & 津波の制御 & 壁の配置 & & & & & …... & & 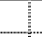 & ..... & & 1 & 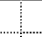 & & & & & & & ] \\
\hline & & & 譬の角度の設計 & & & & 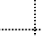 & 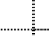 & & & $\ldots$ & & in & 1 & & & & & & & ㅁ] \\
\hline & & & 溝等の設置 & & & $\ldots$ & & : & 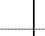 & & . & & 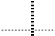 & I & & & & & & & ]..] \\
\hline & & & 哺装表面のデザイン & & 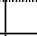 & 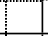 & & 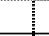 & 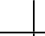 & 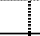 & 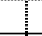 & 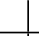 & 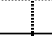 & 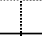 & & 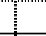 & 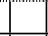 & "nes & & & b] \\
\hline & & 津波の遮断 & 防波堤 & & (2) & $\rightarrow$ & 0 & (2) & $\rightarrow$ & (a). & $\rightarrow[$ & of & 이 & $\rightarrow$ & $\rightarrow C$ & D & & $x$ & & 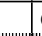 & 0 \\
\hline & & & 防潮堤 & $(0)$ & (0) & $\rightarrow$ & 0 & (ㅇ) & $\rightarrow$ & 이 & $\rightarrow$ & o. & 이 & $\rightarrow$ & $\rightarrow$ & & & $x$ & & .......... & ㅁ] \\
\hline & & & 防壁 & & & & & & & (a). & $\rightarrow[$ & $\rightarrow$ & $\rightarrow$ & $\rightarrow$ & $\rightarrow$ & ........ & ....... & $\ldots$ & 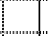 & ....... & ?] \\
\hline & & & 河川堤防 & & 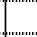 & $\ldots$ & & 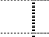 & 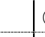 & 이. & $\rightarrow$ & o] & OI- & $\rightarrow$ & $\rightarrow$ & & & & & & \\
\hline & & & 进波水門 & & (3) & "3in & 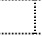 & 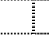 & 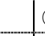 & (a) & $\rightarrow$ & o. & 이 & $\rightarrow$ & $\rightarrow$ & & & & & 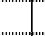 & \\
\hline & & & 段上基盤・土地の棚上げ & & (2) & $\rightarrow$ & $\rightarrow$ & (2) & $\rightarrow$ & (a). & $\rightarrow$ & o] & O & $\rightarrow$ & $\rightarrow$ & & & (3) & .... & (0) & ] \\
\hline & & & 防浪ビル & & & & & 1 & & Ee & . & ol. & $\mathrm{O}$ & $\rightarrow$ & $\rightarrow$ & & & & & ........ & \\
\hline & & & 駐車場施設 & & 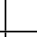 & 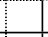 & 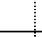 & 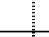 & - & 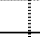 & 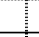 & - & 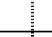 & 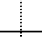 & & & & 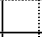 & 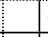 & (0) & b] \\
\hline & & 構造物の強化 & 護岸整備 & & 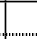 & 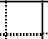 & 0 & (-) & $\rightarrow$ & o. & $\rightarrow$ & of & O & $\rightarrow$ & $\rightarrow$ & ........ & & ....... & 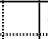 & (0) & 2 \\
\hline & & & 而震化 & & $x$ & & 0, & O & $\rightarrow$ & O.]. & $\rightarrow$ & o. & O잉 & $\rightarrow$ & $\rightarrow$ & 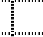 & & 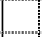 & & 1 & b] \\
\hline & & & 而浪化 & & & & $0]$ & (2) & $\rightarrow$ & o. & $\rightarrow[$ & o] & 이 & $\rightarrow[$ & $\rightarrow$ & 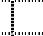 & & (Q) & $\rightarrow$ & $\rightarrow$ & 5] \\
\hline & & & その他産業施設付带設備の防御（危険物対策を含む） & & & & & & & ㅇ. & $\rightarrow$ & ol & 이 & $\rightarrow=$ & $\rightarrow$ & & & & & (0) & 5] \\
\hline & & & 施設ごとの要求に応じた建築基準（設計・施工・監理ほか） & & & & & & & & & o] & o: & $\rightarrow$ & $\rightarrow$ & .... & & & & (2) & 2] \\
\hline & & & 既存施設の改修・補強 & & & & & & & & & o] & 0 & $\rightarrow$ & $\rightarrow$ & 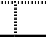 & & & & (a) & ] \\
\hline 事前準備 & 被害想定の実施 & & & & 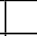 & 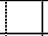 & 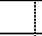 & 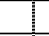 & 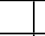 & 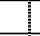 & 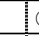 & O & $\mathrm{O}-$ & $\rightarrow$ & $\rightarrow$ & 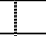 & & & 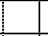 & 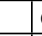 & D \\
\hline & リスク情報公開 & & 被害想定 & & 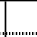 & 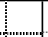 & & 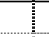 & & 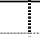 & 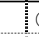 & of & O & $\rightarrow$ & $\rightarrow$ & 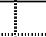 & & & & 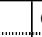 & 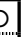 \\
\hline & & & ハザードマップ & & & & & & & & (0). & ol. & 0,0 & 5[ & $\rightarrow$ & & & & & (2) & 5] \\
\hline & & & 避難マップ & & & & & & & 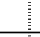 & & o[ & $\mathrm{O}$ & 5 & $\rightarrow$ & & & & & (2) & b] \\
\hline & 教育・啓発活動 & & & & & & & & & o. & $\rightarrow$ & O & $\mathrm{OH}$ & $\rightarrow$ & $\rightarrow$ & 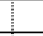 & & & 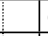 & (2) & D \\
\hline & 津波記念碑整備 & & & & 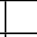 & 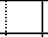 & - & 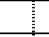 & E & & s & 0 & 0 & + & $\rightarrow$ & 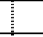 & & & & - & \\
\hline & 防災組織の確立 & & & & & & & 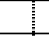 & & 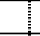 & T & 0 & 0 & {[} & $\rightarrow$ & 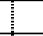 & & & & + & 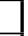 \\
\hline & 津波防災訓練 & & & & & & & & & 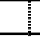 & & of & 0, & {[} & $\rightarrow$ & 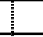 & & & & - & \\
\hline 早期警報 & 津波観測 & & & & & 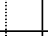 & 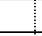 & 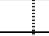 & & 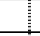 & & 0 & 0 & $\rightarrow$ & $\rightarrow$ & 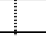 & & & & (2) & o \\
\hline & 警報システム & & & & 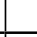 & 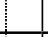 & 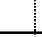 & s & (2) & 0 & $\rightarrow$ & 0 & 0 & L & $\rightarrow$ & $\Delta$ & & & (०) & (0) & o \\
\hline 災害対応 & 応急体制 & & & & & 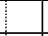 & 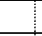 & 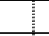 & 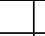 & & I & 0 & 0 & $\rightarrow$ & $\rightarrow$ & 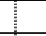 & & & & 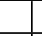 & \\
\hline & 避難 & 水平避難 & 隦難ルート（整備・指定） & & (0) & $\rightarrow$ & 0 & (2) & $\rightarrow$ & 0 & $\rightarrow$ & of & 0, & $\rightarrow$ & $\rightarrow$ & & & & 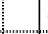 & (2) & o \\
\hline & & & 避難場所（整備・指定） & & & & 0 & $\rightarrow$ & $\rightarrow$ & 0. & $\rightarrow$ & o] & 이, & $\rightarrow$ & $\rightarrow$ & & & & & (a) & b] \\
\hline & & 垂直避難 & 垂直避難ルートのの確保 & & 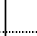 & & & & & & & & & Io & D. & & & & & & o \\
\hline & & & 湕波避難用建造物の整備 & & & & & & & & & & & c & 2. & & & & & & 2] \\
\hline & & & 建波避難ビルの指定 & & & & & 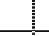 & & & & & 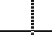 & 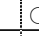 & D & & & & & & b] \\
\hline & & サインの設置 & & & & & & & & & & $\mathrm{O}$ & o! & $\rightarrow$ & $\rightarrow$ & & & & & (2) & 0 \\
\hline & & 弱者対策 & & & & & & & & & S & 0 & 0 & $f$ & $\rightarrow$ & & & & & & \\
\hline 復旧・復興 & 全体計画・意義 & & & & & & & & & & & & & 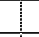 & & & & & & & 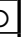 \\
\hline & 記念事業 & & & & $x$ & (2) & 0 & (0) & $\rightarrow$ & (1): & $\rightarrow$ & 0 & 0 & 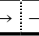 & $\rightarrow$ & & & & & (2) & $\Leftrightarrow$ \\
\hline
\end{tabular}


成する。しかし，津波を前提としたものではなかった。1946 年の津 波が発生する以前の 1940 年にマスタープラン ${ }^{20)}$ が策定されるが, 想定する災害としては火災と洪水であり, 津波については記述がな い。しかしながら, 沿岸部のオープンスペースの必要性については 述べられており，それが 1946 年の津波の後に活かされていく。その 際に, 田老の事例から津波被害軽減のための防潮堤や防波堤の建設 が検討されているが, 費用対効果を考慮した結果, 見送られている 8)。両地域がともに被害を受けた 1960 年チリ津波後の復興により, どちらも街に大きな変化がもたらされる。しかし, 三陸で構造物に よる被害抑止策が進んだのに対し, ヒロではKaiko’ o Project ${ }^{21)} に$ 基づき都市の面的な計画である土地利用規制が中心となっていった。 三方を山に囲まれ高地移転が容易ではなかった三陸地域と, 平地の 広がるヒロとの地勢の違いが大きく影響を与えていたと考えられる。

\section{5. まとめ}

本稿では, 過去の文献に基づき, 日米の津波常襲地域である三陸 海岸地域とヒロを基軸として, それぞれの津波災害とその後の都市 復興, そして各時代に策定された津波防災計画の変遷を整理し，そ の比較考察を報告した。日米の社会, 地区特性, 時代による違いは 当然存在しており, 時代背景などから説明をすることは可能である が，より重要な点は，防災先進国である二国の津波対策に対する考 え方の視点の違いを知り, 補完し合い, 将来の防災に活かすことで ある。本研究では, 定量的な分析には至っていないが, このように 整理することにより，視点の違いをあらためて認識することができ た。ここで得られた知見を, 両国および諸外国における今後の津波 防災都市計画・復興計画に活かすことが重要である。

\section{謝辞}

本稿はフルブライト研究員プログラム 2009-2010 “Comparative Study of the Policy and Urban Planning for Disaster Management in USA and Japan”の一環としてハワイ大学ヒロ校を拠点に実施し た調査に基づく研究成果である. 資料収集等に協力してくださった Tsunami Museum および大学図書館, 日米教育委員会, Institute of International Educationに対し, 記して謝意を表する.

\section{参考文献}

1）山下文男：哀史三陸大津波，青磁社，1982

2）山下文男編著：写真記録 近代日本津波誌，青磁社，1984

3）山下文男：防災講座 津波の心得, 青磁社, 1985

4) 山下文男編著発行 : 明治三陸津波百周年記念 写真と絵で見る一明治三陸 大津波, 1995

5）吉村昭：三陸海岸大津波，文藝春秋，2004

6）中央防災会議 災害教訓の継承に関する専門調査会：1896 明治三陸地震 津波報告書, 内閣府, 2005, http://www.bousai.go.jp/jishin/chubou/kyou kun/rep/1896-meiji-sanrikuJISHINTSUNAMI/index.html, 2010 年 5 月 17 日人手

7）中央防災会議 災害教訓の継承に関する専門調査会：1960 チリ地震津波 報告書, 内閣府, 2010, http://www.bousai.go.jp/jishin/chubou/kyoukun/ rep/1960-chile\%20JISHINTSUNAMI/，2010 年 5 月 17 日入手

8) Dudley, Walter C., and Lee, Min (1998). Tsunami ! (2nd ed.). Hon olulu: University of Hawai'i Press.

9) U.S. Department of the Interior and U.S. Geological Survey, Comp iled by Atwater, Brian F., Cisternas V., Marco, Duldley, Walter C.,
Hendley, James W. II, and Stauffer, Peter H. (1999). Surviving a $T$ sunami-Lessons from Chile, Hawaii, and Japan, U.S. Geological Su rvey Circular 1187. United States Government Printing Office.

10) Dudley, Walter C., and Stone, Scott C. S. (2000). The Tsunami of 1946 and 1960 and the Devastation of Hilo Town. Virginia Beach: Donning.

11）首藤伸夫 :「アメリカの津波対策」, 高橋博, 竹田厚, 谷本勝利, 都司嘉 宣, 磯崎一郎編纂『沿岸災害の予知と防災 一津波・高潮にどう備えるか 一』、白亜書房, pp. 138-150, 1988

12）首藤伸夫 :「第 9 章 チリ地震津波とその後の対策に関する教訓」, 中央防 災会議 災害教訓の継承に関する専門調査会『災害教訓の継承に関する専 門調査会報告書 1960 チリ地震津波』, 内閣府, pp. 196-197, http://ww w.bousai.go.jp/jishin/chubou/kyoukun/rep/1960-chile\%20JISHINTSUN $\mathrm{AMI} / 12 \_$chap9.pdf, 2010 年 5 月 17 日入手

13）村尾修: 八ワイ島ヒロにおける津波復興都市計画と最近の動向 -1960 年チリ地震津波 50 周年現場報告一, 都市計画報告集 No.9-1 (CD-ROM), 日本都市計画学会, pp.12-17, 2010.6

14) The Department of Business, Economic Development \& Tourism, State of Hawaii (2008). 2008 State of Hawaii Data Book Individual Tables, http://hawaii.gov/dbedt/info/economic/databook/2008-individual/, 2010 年 5 月 14 日入手

15）首藤伸夫, 佐竹健治, 松冨英夫, 今村文彦, 越村俊一編 : 津波の事典, 朝倉書店， 2007

16）越村俊一：「第 1 章 三陸地方の津波災害概要」, 中央防災会議 災害教訓 の継承に関する専門調査会『災害教訓の継承に関する専門調査会報告書 1896 明治三陸地震津波報告書』，内閣府， p. 3， http://www.bousai.go.jp/jishin/chubou/kyoukun/rep/1896-meiji-sanrikuJ ISHINTSUNAMI/1896-meiji-sanrikuJISHINTSUNAMI_05_chap1.pdf , 2010 年 5 月 17 日入手

17）杉安和也, 村尾修: 平成 18 年 8 月における津波ハザードマップの公開状 況とコンテンツの比較, 日本都市計画論文集, No.42-3, pp.613-618, 2007.11

18）藤間功司：「第 8 章構造物主体の津波対策の確立とその後」, 中央防災会 議 災害教訓の継承に関する専門調査会『災害教訓の継承に関する専門調 查会報告書 1960 チ リ地震津波』, 内閣府, p. 154, http://www.bousai.go.jp/jishin/chubou/kyoukun/rep/1960-chile\%20JISH INTSUNAMI/11_chap8.pdf, 2010 年 5 月 17 日入手

19）国土庁, 農林水産省構造改善局, 農林水産省水産庁, 運輸省, 気象庁, 建設省，消防庁：津波防災計画における津波対策強化の手引き，1997

20) Territorial Planning Board, Territory of Hawaii in collaboration w ith County Board of Supervisors County of Hawaii (1941). Publicati on No.9 December 1940 Master Plan of the City of Hilo, County of Hawaii, Hawaii. Honolulu: Advertiser.

21) Hawaii Redevelopment Agency (1965). Urban Renewal Plan for the Kaiko'o Project No. Hawaii $R-4$, Hilo, Hawaii.

22) NOAA, USGS, FEMA, NSF, Alaska, California, Hawaii, Oregon, and Washington (2001). Designing for Tsunamis Seven Principles fo r Planning and Designing for Tsunami Hazard, http://nthmp-history. pmel.noaa.gov/Designing_for_Tsunamis.pdf, 2010 年 5 月 26 日入手

23）文部省震災予防評議会 : 津浪災害予防に関寸る注意書, 津波ディジタル ライブラリィ作成委員会, 津波ディジタルライブラリ, http://tdl.civil.toh oku.ac.jp/TSUNAMI/TDL_top.html, 1933

24）目黒公郎，村尾修：都市と防災，放送大学教育振興会，2008

25）建設省河川局，水産庁：津波常襲地域総合防災対策指針（案），津波ディ ジタルライブラリィ作成委員会, 津波ディジタルライブラリ, http://tdl.ci vil.tohoku.ac.jp/TSUNAMI/TDL_top.html, 1978

注

注 1）米国 2000 年国勢調査より

[2010 年 6 月 18 日原稿受理 2010 年 7 月 30 日採用決定］ 